\title{
Information Sharing and Strategic Supplier Partnership in Supply Chain Management: A Study on Pharmaceutical Companies of Pakistan
}

\author{
Ambreen Khan ${ }^{1 *}$, Danish Ahmed Siddiqui ${ }^{2}$ \\ ${ }^{1}$ Research Scholar, Karachi University Business School, University of Karachi, Karachi, PAKISTAN \\ ${ }^{2}$ Associate Professor, Karachi University Business School, University of Karachi, Karachi, PAKISTAN \\ *E-mail for correspondence: ambreenkhan793@gmail.com
}

https://doi.org/10.18034/abr.v8i3.162

\begin{abstract}
The aim of this paper is to distinguish the relationship between different components of supply chain management (SCM) and its impact on the performance of pharmaceutical manufacturing firms in Pakistan. Data has been gathered from 35 pharmaceutical companies located in the big cities of Pakistan. Self-reported questionnaires were used to collect data from the managerial level people working in different pharmaceutical companies of Pakistan. The result indicates that strategic supplier partnership, level of information sharing and quality of information sharing significantly correlates with the performance of manufacturing pharmaceutical firms. The current study will prove fruitful for the organization in improving their performance by implementing concepts of SCM within their companies. The study explored that all independent variables significantly predicted the performance of the firm. Strategic supplier partnerships, quality of information sharing have a positive effect on the performance of pharmaceutical companies whereas the level of information sharing has a negative impact on performance. The findings provide the evidence for previous literature. Results are helpful to policy makers and management to integrate the concepts within the organization to increase the performance of the firm and to win competitive advantage.
\end{abstract}

Key words: Strategic supplier partnership, quality of information sharing. Level of information sharing, firm performance

\section{INTRODUCTION}

The goal of supply chain practices is to ensure that the flow of materials and information should be smooth. To be in competition and to improve the profitability of a firm has become a challenging task for supply chain management as the supply chain is turning out to be an essential task in today's era (Li et al. 2006). So, SCM has become an important phenomenon that has created attention among executives and academic researchers.

The pharmaceutical industry in Pakistan is facing a lot of issues which is purely influenced by governmental on the values of nearly every commodity that is registered in Pakistan, import of raw materials makes a lot of expenditure of foreign exchange. More, challenges are of low Research and development expenditure, political instability. It's difficult for the pharmaceutical industry to increase profit and earn revenue due to these factors. Today, pharmaceutical companies have sufficient knowledge and are aware of the fact that they need to give their central focus to organizational efficiencies and there is an immediate need for an actual supply chain in the companies. The companies should focus on making a robust supply chain to be stable and to remain competitive ahead from other. The objective of SCM (supply chain management) is to integrate information and material both flows flawlessly through the supply chain as a competitive arm, to achieve profitability (Zaman, 2011). Many exploratory researches have been carried out in Pakistan in unlikely industries catering to different aspects of supply chain, however, the studies lack in investigating about the targeted industry area concerning information sharing, quality of information and strategic supplier relation that highlights the gap of previous studies. Therefore, this research has been conducted on the pharmaceutical industry in Pakistan to study the mentioned factors of the business regarding supply chain system. The purpose of the study is to identify the effect 
of these three variables, i.e. (QOI, LOI, and SSP) on manufacturing performance of a firm.

\section{Problem Statement}

An organization's effectiveness is based on its performance. The better performance of an organization helps it to achieve strategic and business objectives. To score the organization performance there are many indicators, focusing on financial performance is one of the aspects. In a broader context, the performance of organization includes assessing all factors such as achieving customer' satisfaction, better quality of products, the economic performance of firms, delivering the product at the right time and reduced cost of services. In the case of Pharmaceutical companies, it is necessary for the companies to produce high-quality product with low cost and to increase the profitability. The pharmaceutical industry with in Pakistan is facing a lot of challenges. There is a need to explore the impact of different components of supply chain management to increase the performance of the pharmaceutical industry in Pakistan. The previous researches have focused on single aspect only to check its impact on the performance of the company. Researches related to the study variables have not given the central focus to Pakistan. So the current study explores the various factors that impact the manufacturing performance of pharmaceutical firms. The present research is helpful in bridging a main research gap by exploring the combined impact of strategic supplier partnership, quality of information and level of information on manufacturing performance of pharmaceutical companies with in Pakistan. It shed light on the different component on the supply chain within developing country like Pakistan.

\section{Research objective}

To examine the relationship among supply chain components i.e. strategic supplier partnership, quality of information sharing, level of information sharing, on the performance of Pharmaceutical manufacturing companies in Pakistan.

\section{Research question}

What are the components of supply chain management that affect the performance of Pharmaceutical manufacturing companies in Pakistan?

\section{Operational Definitions}

Strategic supplier Performance: Can be defined as the prolonged association by company and its contractors. It emphases on straight, ongoing association and is determined in joint planning and solving problem efforts (Agus and Hassan, 2008).

Quality of Information: Comprises of aspects like: timeliness, accurateness, appropriateness, and credibility of exchanged information ( $\mathrm{Li}$ et al.2006).
Level of information: It is the level of information communicated with the other partners of the supply chain. Shared information may range from technical to strategic and market knowledge (Li et al.2006).

Manufacturing Firm Performance: Organizations' performance is a combined construct that tells the position of the business, mainly refers to how well an organization achieves its financial goals and market goals (Li et al. 2006).

\section{LITERATURE REVIEW}

\section{Supply Chain Management Theory}

The concept of focus was on supply chain management and its impact on the organization in last decades. SCM help the profit organization to compete in the market by incorporating the activities within and outside the organization. The concept of SCM is described in the context of strategic relationship with supplier and issues related with purchase and supply of services.

The SCM theory has it ground in management theory which focuses on building collaborative advantage instead of competitive advantages (Porter, 1985). The SCM research model has also grounded on the relational view within the organization (Dyer \& Singh, 1998). SCM framework also incorporates buyer and supplier long term relationship and maintain a superior relationship with another partner in the market. A research framework proposed by Chen \& Paulraj (2003). SCM has various concept related to the purchase and supply of the material. Plenty of empirical research work has already been done on SCM framework in broader disciplines. However, there is still a lack of applicability of the framework within the organization (Al-Shboul, 2017). The present study is helpful in bridging the gap between SCM theory and its applicability with in Pakistani context. Three main constructs of SCM that are strategic supplier relationship, quality of information, level of information sharing and performance of the firm are the central focus of the present investigation. Manufacturing firm performance is the outcome variable.

\section{Empirical View}

The empirical sight has been taken by the previous scholarly studies.

\section{Strategic Supplier Partnership}

To respond to the challenges with in competitive world supply chain management is an important concept that makes a firm capable of dealing with its supply partner effectively so that long term positive relationships can be established (Sambasivan et al, 2013). In the supply, chain partnership result in greater information flow, low-level uncertainty and better performance of the company. The most important way to manage the supply chain is to build the strategic partnership with suppliers. 
Pharmaceutical companies usually lie at the center of all the suppliers that supply different types of products and services to add value to the pharmaceutical companies and this is known as the supplier base as stated by Perona \& Miragliotta (2004). With the increase in a number of suppliers, the marked differentiation in supply base also increases and the interaction between suppliers and manufacturing companies gets difficult. The operational load caused as a result of the complex interaction mostly exists at the upstream side of the supply chain where there are chances that disruptions can take place due to complications in acquiring the components.

Strategic partnership with in the supply chain management is supposed to result in increased benefits for the pharmaceutical companies. Supplier Partnership is related to an alliance between two or more than two firms to facilitate each other in core areas such as research, product manufacturing, marketing and, distribution. According to (Khan et al, 2015) the partnership with such supplier and information integration have an impact on the performance of the supply chain.

\section{Level of information sharing}

Information sharing is a vital component in successful supply chains. According to (Lee \& Whang 2000), the information sharing is defined as the transfer of product related information such as inventory levels, delivery schedules, order status, and performance. The information provided to the pharmaceutical firms with broader visibility, improvement in production and manufacturing performance of the company. The degree of uncertainty and misunderstanding is overcome with the help of continuous and open communication activities that are carried out among the partners of the supply chain (Agrawal \& Pak, 2001).

According to supply chain management theory, the close relationship between supply partners is very much necessary to sustain the competition. The manufacturing companies cannot survive alone, rather than a company has to build alliances so that cost of reduction gets less and quality can gets increase. Growing demands of augmented quality of the product and services make it necessary that manufacturing companies need to be more responsive. The correctly conveyed information act as a linkage between members of the supply chain and thus is used to coordinate all the activities with in supply chain smoothly. In a study done on Chinese economy, it was explored that information sharing have an insignificant impact on business performance due to rise in the practice of having informal ties which has steered to decrease the significance of information sharing on the performance of firms. (Liu, 2013).

\section{Quality of information sharing}

As information sharing is essential, the quality of the shared information also matters a lot. The quality is related to the usefulness of the shared info, its accuracy and, accessibility. Sharing the low quality of information is not likely to benefit the supplier chain participants as its lack the elementary elements (Huang et al, 2003). Proper quality information to be floated is necessary with in supply chain partners in the pharmaceutical industry. Without it, companies cannot guarantee their products are up to the quality and safety standard or not.

The quality of information is an umbrella term that has been identified by various researchers to pinpoint its dimensions. Some of the indicators include reputation, interpretable, complete, value added, secure, objective, time-related, accurate, available, reliable and protected (Naumann \& Rolker, 2000). If the shared information is distorted, then it is related to severe consequences (Childerhouse et al, 2003). It is a significant factor of the study as an incomplete information will lead an organization to ascertain need and this will impact the manufacturing performance of the organization negatively.

Information quality is a crucial aspect within the organization. There is a need in the organization to use information as their strategical asset, that have a potential to impact the performance of organization,

\section{Manufacturing Firm Performance}

Performance is an accomplishment of a task against predefined standards that has been set before. Some indicators of criteria include accuracy standard, cost, speed and completeness of assignment. Manufacturing performance is related to fulfilment of some targets that the company have set for the current period and it is related to efficiency and effectiveness of the business. It is also related to the ability of a manufacturing company to achieve the certain objectives related to increased profit for the company, high quality of the product, greater shares in the market and surviving with in the competitive environment (Kilonzo, 2014). According to Corina, Liviu \& Roxana (2011) there are some financial and nonfinancial pointers that are used to evaluate the manufacturing performance of the organization.

Different indicators available and are used for the purpose of determining the manufacturing performance and these measures include: return on assets (ROA), return on equity (ROE) and the Gross profit margin (GPM), Net operating profitability (NOP).

The prime goal with in the concept of supply chain management is to increase productivity with low cost and to achieve market share and generate revenue in the long run. Every organization has different aspects of measuring and accessing level of performance Johnson et al, (2006) these relationships are related to financial performance, reducing the time of production, creativity, quality of products and improvement in overall process design. The partnership is related to better market representation, assess to new technology and high return rate of 
investment. Criteria for measuring the performance of the organization includes market share, investment return, profit margin and overall position with in the competitive market. According to Li et al. (2006) implementing practices of SCM is linked with better performance and competitive advantage of the organization. The competitive advantage in turn positively impacted the performance of the organization. So bi-directional relationship exists between competition and performance of firms.

\section{ReseARCh Method}

\section{Hypothesis development}

$\mathrm{H}_{\mathrm{a} 1}$ : There is a significant relationship between strategic supplier partnerships and performance of pharmaceutical manufacturing companies

$\mathrm{H}_{\mathrm{a} 2}$ : There is a significant relationship between the quality of information sharing and performance of pharmaceutical manufacturing companies

$\mathrm{H}_{\mathrm{a} 3}$ : There is a significant relationship between the level of information sharing and performance of pharmaceutical manufacturing companies

$\mathrm{H}_{\mathrm{a} 4}$ : There is a significant impact of strategic supplier partnerships, quality of information sharing and level of information sharing on the performance of pharmaceutical manufacturing companies

\section{Research Design}

The present study is quantitative. Data is collected using selfreported questionnaires, and statistical facts generated (Creswell et al, 2003). The research type for the present study is descriptive. In descriptive statistics, the raw data obtained from participants is summarized applying different statistical techniques (Bryman, \& Cramer, 1990).

\section{Sampling design}

The population of the current study comprise of managers working in pharmaceutical companies with in Pakistan. Convenient Sampling technique is used. The sample size for the current study is 200 employees.

\section{Instrumentation}

Al-Shboul et al., (2017) have designed an instrument to measure the different constructs of the supply chain management. The responses were coded on five point Likert scale 1 = strongly disagree, 2 = Disagree, $3=$ neither, $4=$ Agree and $5=$ strongly Agree for the SSP, QOI, LOI \& for the MP the responses were coded on five point 1 =Significant Decrease, 2 = Decrease, 3 = same as before, 4 $=$ Increase and $5=$ Significant Increase.

\section{Data collection}

A web based survey was used to collect data as it is faster, simple and cost effective way of data collection by quoting five responses for every question.

\section{Statistical techniques}

\section{Pearson Correlation}

To estimate the strength of a relationship between two variables Pearson correlation is used in the present study. Correlation value ranges from -1 to +1 . The closer the value towards 1, stronger is the strength of the relationship. A positive sign indicates that both variables are positively correlated which means an increase in one variable will result in an increase in other variable and vice-versa. Where-as on the other hand a negative sign indicates that there is a negative correlation between two the variables. Increase in one variable result in a decrease in the second variable (Saunders et al, 2009).

\section{Content Validity}

Validity refers to the ability of the test to measure what it is intended to measure. For a questionnaire validity, it's necessary that items are relevant to the construct (Sekaran, 2003).

\section{Factor analysis}

Factor analysis was used to reduce the total number of items to a manageable factor. The factor matrix was rotated using the orthogonal, Varimax rotation. However, the diagonals on the matrix should exhibit an overall measure of sampling adequacy (MSA) of 0.5 or above.

\section{Multiple Regression analysis}

The analysis is used to measure the strength of the relationship between predictor and outcome variable. The R2 value tells about how much variance in dependent variable is explained by the independent variable. The coefficient value numbers ranges from 0 to +1 (Saunders et al, 2009).

\section{DATA AnALYSIS}

In this section, we analyze the relationship and impact of and among SSP, LOI, QOI and MP. The data was analysed by performing the statistical techniques using SPSS software.

Table 1: Reliability Statistics

\begin{tabular}{lcc}
\hline \multicolumn{1}{c}{ Variables } & $\begin{array}{c}\text { Cronbach's } \\
\text { alpha }\end{array}$ & $\begin{array}{c}\text { No. of } \\
\text { items }\end{array}$ \\
\hline Strategic supplier partnership (SSP) & .724 & 10 \\
Quality of information sharing (QOI) & .631 & 5 \\
Level of information sharing (LOI) & .773 & 6 \\
Manufacturing Firm's performance (MFP) & .718 & 7 \\
\hline
\end{tabular}

Statistical test of reliability (Cronbach's alpha) is used. Table 1 provide the value of Cronbach's alpha for all the variables individually. SSP, QOI, LOI and MFP value of Cronbach's alpha falls between 0.60 to 0.80 , thus, it can be concluded that the measures have an acceptable level of reliability. Factor analysis was used to reduce the total number of items to a manageable factor. Table 2 presents the factors loadings of variable constructs after deleting the items that show either low factor loading (0.40). 
Table 2: Factor Analysis

\begin{tabular}{|c|c|c|c|c|}
\hline \multirow{2}{*}{ Items } & \multicolumn{4}{|c|}{ Rotated Component Matrix } \\
\hline & Factor 1 & Factor 2 & Factor 3 & Factor 4 \\
\hline Our firm relies on a few dependable suppliers & 0.461 & & & \\
\hline Our firm considers quality factor one of main criterion in selecting our suppliers & 0.483 & & & \\
\hline Our firm has continuous improvement programs that include our key suppliers & 0.604 & & & \\
\hline Our firm provides any help to improve the quality of suppliers' products & 0.839 & & & \\
\hline New product development processes in our firm is included in our key suppliers & 0.637 & & & \\
\hline Our firm relies on a few high quality suppliers & 0.588 & & & \\
\hline Our transactions with suppliers do not have to be closely monitored/supervised & 0.507 & & & \\
\hline We expect to leverage the business between us and our suppliers in the future & 0.471 & & & \\
\hline Here is a slimier understanding between us and our suppliers about aims and objectives & 0.839 & & & \\
\hline Our suppliers deals with us in an open and honest way & 0.635 & & & \\
\hline Information exchange between our firm and our partners is timely & & & & 0.537 \\
\hline Information exchange between our firm and our partners is accurate & & & & 0.659 \\
\hline Information exchange between our firm and our partners is complete & & & & 0.879 \\
\hline Information exchange between our firm and our partners is adequate & & & & 0.472 \\
\hline Information exchange between our firm and our partners is reliable & & & & 0.881 \\
\hline In case of any change needed, our partners will be informed in advance & & 0.725 & & \\
\hline Our firm sharing proprietary information with trading partners & & 0.694 & & \\
\hline If there are any issues that might affect our firm, our trading partners will keep us fully informed & & 0.67 & & \\
\hline Our trading partners share firm knowledge to develop our core firm's processes & & 0.777 & & \\
\hline Our firm exchange information with trading partners to establish our business planning & & 0.67 & & \\
\hline $\begin{array}{l}\text { Our firm keeps in touch frequently with our trading partners and informs each other about any } \\
\text { changes/events that may affect the other partners }\end{array}$ & & 0.772 & & \\
\hline Market share is growing & & & 0.437 & \\
\hline The growth of market share & & & 0.728 & \\
\hline Growth of sales is growing & & & 0.727 & \\
\hline Return on investment & & & 0.795 & \\
\hline Growth in return on investment & & & 0.647 & \\
\hline Profit margin on sales & & & 0.80 & \\
\hline Overall competitive position & & & 0.647 & \\
\hline
\end{tabular}

Ten items loaded onto Factor 1 which is related to Strategic supplier partnership (SSP). Six items loaded onto Factor 2, represented Level of information sharing (LOI), whereas seven items loaded onto Factor 3 representing Manufacturing Firm's performance (MFP). Lastly, five items loaded onto factor 4, resulted in Quality of information (QOI).

Table 3: Correlation Analysis

\begin{tabular}{|c|c|c|c|c|c|}
\hline \multicolumn{6}{|c|}{ Correlations } \\
\hline & & $\begin{array}{c}\text { Firm } \\
\text { Performance }\end{array}$ & $\begin{array}{l}\text { Strategic Supplier } \\
\text { Partnership }\end{array}$ & $\begin{array}{l}\text { Quality of } \\
\text { Information }\end{array}$ & $\begin{array}{c}\text { Level of } \\
\text { Information }\end{array}$ \\
\hline Pearson & Firm Performance & 1.000 & .416 & .502 & .262 \\
\hline Correlation & Strategic Supplier Partnership & .416 & 1.000 & .453 & .653 \\
\hline \multirow{6}{*}{$\begin{array}{c}\text { Sig. } \\
\text { (2-tailed) }\end{array}$} & Quality of Information & .502 & .453 & 1.000 & .332 \\
\hline & Level of Information & .262 & .653 & .332 & 1.000 \\
\hline & Firm Performance & & .000 & .000 & .000 \\
\hline & Strategic Supplier Partnership & .000 & & .000 & .000 \\
\hline & Quality of Information & .000 & .000 & & .000 \\
\hline & Level of Information & .000 & .000 & .000 & \\
\hline
\end{tabular}

To test the relationship a correlation test was performed among SSP, QOI, LOI and MP. Table 3 illustrates the result of the correlation analysis with coefficient and $\mathrm{P}$ value. The significant (2-Tailed) value and correlation coefficient (r) for firm performance and Strategic supplier partnerships equals to $(p=0.000, r=0.416)$. The result shows there is a statistically significant moderate positive relationship between Strategic supplier partnerships and firm performance and according to study the alternative hypothesis (H1) is accepted.

Quality of information and firm performance have a moderate positive relationship with the sig and coefficient value $(p=0.000, r=0.502)$ it indicates that alternative hypothesis (H2) is accepted. The significant (2-Tailed) 
value and correlation coefficient $(r)$ for the level of information and firm performance equals to $(p=0.000$, $r=0.262$ ). The result shows that there is a statistically significant low positive relationship between the LOI and firm performance and according to study the alternative hypothesis (H3) is accepted.

Table 4: Regression Analysis

\begin{tabular}{|c|c|c|c|c|}
\hline \multicolumn{2}{|c|}{ Variables } & Coefficients & $\mathrm{T}$ & Sig. \\
\hline \multicolumn{2}{|c|}{ (Constant) } & .609 & 2.080 & .039 \\
\hline \multicolumn{2}{|c|}{ Strategic Supplier Partnership } & .317 & 3.140 & .002 \\
\hline \multicolumn{2}{|c|}{ Quality of Information } & .401 & 5.899 & .000 \\
\hline \multicolumn{2}{|c|}{ Level of Information } & -.044 & 5.230 & .601 \\
\hline Model Summary & R Square & \multicolumn{3}{|c|}{$29.8 \%$} \\
\hline \multirow{2}{*}{ Anova } & $\mathrm{F}$ & \multicolumn{3}{|c|}{27.681} \\
\hline & Sig.(F-stat) & \multicolumn{3}{|c|}{0.000} \\
\hline
\end{tabular}

A multiple the linear regression test was performed to examine the impact of all the independent variable on the dependent variable and predict the values of variables for regression equation. Table IV shows the result of regression analysis which is divided into three different categories. The model summary section displays the degree of goodness fit of regression model. In this section, the value of $R 2$ is (0.298) which states that only $29.8 \%$ of the variation is showed by independent variable as per the model.

Through the ANOVA section, we can see that the F-test value (27.681) with sig value of (0.000) shows that there is a statistically significant relationship among quality of information sharing, level of information sharing and strategic supplier partnerships on the performance of pharmaceutical companies Hence the hypothesis (H2) is accepted. Quality of information sharing, level of information sharing and strategic supplier partnerships have an impact on the performance of pharmaceutical companies.

The values of the unstandardized coefficient (B) and the significance level of all the independent variables used shown in the coefficient section of the table. (B) Tells us the nature of the relationship between dependent and independent variables individually. As we can see the values $\mathrm{B}=0.317, \mathrm{~B}=0.401$ and $\mathrm{B}=-0.044$ of $\mathrm{SSP}, \mathrm{QOI}$ and LOI respectively. In conjunction to this if we study the values $p=0.002, p=0.000$ and $p=0.601$ of Strategic supplier partnerships, quality of information sharing and level of information sharing, the results explains that there is a significant, positive impact of Strategic supplier partnerships, quality of information sharing on firm performance and a negative and insignificant impact on level of information sharing on firm performance.

As per the fact that the level of information solely contributes to enhancing the operational performance of firm rather than improving the manufacturing performance as a whole. Negative coefficient tells us that while the increase in the value of the level of information will lead to the decrease in the value of manufacturing performance which indicates that LOI correlation with manufacturing firm performance is negative. Information sharing shows an insignificant relationship with the performance of firm which is consistent with previous research conducted in China. A study which shows the negative correlation (Liu, 2013) demonstrating that information sharing has insignificant impact on firm performance due to the fact that the emerging practice of increasing the informal ties in the Chinese economy has lessened the significance of information sharing in enabling the companies to earn higher profits. Therefore, in the context of SCI, information plays a big role in generating normal profits, however, it has no adequate role in getting superior profits.

The unstandardized coefficient value (B) is used to form a regression equation which is,

$\mathrm{FP}=0.609+0.317(\mathrm{SSP})+0.401(\mathrm{QI})-0.044(\mathrm{LOI})+\mathrm{e}$

Here FP refers to a firm performance that is our dependent variable. 0.609 is constant, $0.317,0.401$ and -0.044are elasticizes of Strategic supplier partnerships, quality of information sharing and level of information sharing respectively. SSP, QI, and, LOI are used for Strategic supplier partnerships, quality of information sharing and level of information sharing respectively, whereas e is error term.

\section{LIMITATION AND ROAD TO FUTURE RESEARCH}

In the present study there were some specific variables that contributed in the investigation. The study is relying on only pharmaceutical industry, in future research can be extended to other productions in Pakistan. It will lead to the confirmation that implementation components of supply chain management resulted in a positive outcome for all industries. Only three dimensions of supply chain management practices were focused currently. In future research can be conducted by taking other components such as infrastructures, customer satisfaction, and supplier responses.

In the present study, only employees of the pharmaceutical companies are taken. In future for indepth exploration, the data can be collected from the customer as well as a supplier, so that picture for the relationship between variables become clearer. Supply chain practices are affected by a large number of factors such as firm size, market share, market performance, etc. These aspects are not the part of the present study. In future, these aspects must be incorporated in order to draw more accurate and reliable results.

\section{CONCLUSION}

The purpose of present study is to investigate the nature of the relationship between strategic supplier partnership, level of information sharing, quality of information sharing and performance of the firm. Three independent variables i.e. QOI, LOI and, SSP were examined to check their impact on the performance of pharmaceutical companies. For this purpose, the pharmaceutical industry 
was chosen as it's growing rapidly in Pakistan, yet its facing a lot of issues and challenges. During the past decades, the concept of supply chain management has been adopted in various firms to see its impact on the organizations. It was found that implementing the components of supply chain management is positively associated with both financial and business performance of the firms (Agus, 2008). The present study is also aimed to explore the impact of different components of SCM on the performance of Pharmaceutical firms with in Pakistan.

The current study will prove fruitful for the organization in improving their performance by implementing concepts of SCM within their companies. The study found that all independent variables significantly predicted the performance of the firm. SSP \& QOI have a positive impact on the performance of pharmaceutical companies whereas LOI sharing has a negative effect on performance. The framework used for the current study can serve as a useful study to the other industries of Pakistan. It will help the policy makers and management to take the decisions that are in favour of development of an organization.

\section{REFERENCES}

Agrawal, M. K., \& Pak, M. H. (2001). Getting smart about supply chain management. The McKinsey Quarterly, 22-22.

Agus, A. \& Hassan, Z. (2008).The strategic supplier partnership in a supply chain management with quality and business performance. International Journal of Business and Management Science, 1(2), 129-145.

Agus, A. (2008). The strategic supplier partnership in a supply chain management with quality and business performance. International Journal of Business and Management Science, 1(2), 129.

Agus, A., \& Makhbul, Z. K. M. (2008). The Importance of Strategic Supplier Partnership in Supply Chain Management in enhancing Product Quality Performance and Business Performance. In $13^{\text {th }}$ International Conference on ISO (Vol. 9000).

Al-Shboul, M. D. A. R., Al-Shboul, M. D. A. R., Barber, K. D., Barber, K. D., Garza-Reyes, J. A., Garza-Reyes, J. A., ... \& Abdi, M. R. (2017). The effect of supply chain management practices on supply chain and manufacturing firms' performance. Journal of Manufacturing Technology Management, 28(5), 577-609.

Baihaqi, I., \& Sohal, A. S. (2013). The impact of information sharing in supply chains on organisational performance: an empirical study. Production Planning \& Control, 24(8-9), 743-758.

Bryman, A., \& Cramer, D. (1990). Quantitative data analysis for social scientists. Taylor \& Frances/Routledge.

Caplice, C. \& Sheffi, Y. (1994). A Review and Evaluation of Logistics Metrics. The International Journal of Logistics Management, 5(2): 11-28

Chen, I. J., \& Paulraj, A. (2003). Towards a theory of supply chain management: the constructs and measurements. Journal of operations management, 22(2), 119-150.
Childerhouse, P., \& Towill, D. R. (2003). Engineering the seamless supply chain. The International Journal of Logistics Management, 14(1), 109-120.

Childerhouse, P., Hermiz, R., Mason-Jones, R., Popp, A., \& Towill, D. R. (2003). Information flow in automotive supply chains-present industrial practice. Industrial Management \& Data Systems, 103(3), 137-149.

Chin, K. S., \& Pun, K. F. (2002). A proposed framework for implementing TQM in Chinese organizations. International Journal of Quality \& Reliability Management, 19(3), 272-294.

Corina, G., Liviu, I., \& Roxana, S. (2011). Determinants of organizational performance: The case of Romania. Management and Marketing Challenges for the Knowledge Society, 6 (2), 285-300.

Creswell, J. W., Plano Clark, V. L., Gutmann, M. L., \& Hanson, W. E. (2003). Advanced mixed methods research designs. Handbook of mixed methods in social and behavioral research, 209, 240.

Crosby, P.B. (1979). Quality is Free. New York: McGraw-Hill. ISBN 0-07-014512-1.

Das, A., Narasimhan, R., \& Talluri, S. (2006). Supplier integration - finding an optimal configuration. Journal of Operations Management, 24(5), 563-58

De Kluyver, C. A., \& Pearce, J. A. (2006). Strategy: a view from the top. An executive perspective.

Dyer, J. H., \& Singh, H. (1998). The relational view: Cooperative strategy and sources of inter-organizational competitive advantage. Academy of management review, 23(4), 660-679.

Glenn Richey Jr, R., Chen, H., Upreti, R., Fawcett, S. E., \& Adams, F. G. (2009). The moderating role of barriers on the relationship between drivers to supply chain integration and firm performance. International Journal of Physical Distribution \& Logistics Management, 39(10), 826-840.

Hasan, Z. (2008). Examining the Association between Benchmarking In TQM and Performance: An Empirical Research for Change. Journal of Faculty of Business, Univesity Teknologi MARA, Shah Alam, Malaysia.

Huang, G. Q., Lau, J. S. K., \& Mak, K. L. (2003). The impacts of sharing production information on supply chain dynamics: A review of the literature. International Journal of Production Research, 41(7), 1483-1517.

Johnson, J.C., Wood, D.F., Wardlow, D.L., \& Murphy, R. (2006). Contemporary Logistics (7th Ed.) Englewood Cliffs, NJ: Prentice-Hall.

KCTS. (2009). Measures of Performance in Lean, KCTS Knowledge Sheet, 1(2), 1-4

Khan, S. A., Liang, Y., \& Sumaira, S. (2015). The effect of buyersupplier partnership and information integration on supply chain performance: an experience from Chinese manufacturing industry. International Journal of Supply Chain Management, 4(2)

Kilonzo, G. (2014). Procurement best practices and organizational performance: Case study of Cadbury's Kenya Limited - Nairobi. Unpublished MBA thesis, University of Nairobi Kulp, S. C., Lee, H. L., \& Ofek, E. (2004). Manufacturer benefits from information integration with retail customers. Management Science, 50(4), 431-444 
Klischewski, R. \& Scholl, H.J. (2008). Information quality as capstone in negotiating e-government integration, interoperation and information sharing. Electronic Government, an International Journal, 5(2), 203225.

Lee, H. L., \& Whang, S. (2000). Information sharing in a supply chain. International Journal of Manufacturing Technology and Management, 1(1), 79-93.

Lewis, A., (2006). The effects of information sharing, organizational capability and relationship characteristics on outsourcing performance in the supply chain: an empirical study. Dissertation (PhD). The Ohio State University, 1-169.

Li, S., \& Lin, B. (2006). Accessing information sharing and information quality in supply chain management. Decision support systems, 42(3), 1641-1656.

Li, S., Ragu-Nathan, B., Ragu-Nathan, T.S., \& Rao, S.S. (2006). The impact of supply chain management practices on competitive advantage and organizational performance. Omega, 34(2): 107-124

Li, X. \& Wang, Q. (2007). Coordination mechanism of supply chain systems. European Journal of Operational Research, 179(1): 1-6.

Liu, H. ( 2013). Effects of supply chain integration and market orientation on firm performance Evidence from China.

Maheswari, B., Kumar, V. \& Kumar, U. (2006). Optimizing success in supply chain partnerships. Journal of Enterprise Information Management, 9(3): 277-291

Marinagi, C., Trivellas, P., \& Reklitis, P. (2015). Information quality and supply chain performance: The mediating role of information sharing. Procedia-Social and Behavioral Sciences, 175, 473-479.

Marinagi, C., Trivellas, P., \& Reklitis, P. (2015). Information quality and supply chain performance: The mediating role of information sharing. Procedia-Social and Behavioral Sciences, 175, 473-479.

McAdam, R., \& Henderson, J. (2002). Influencing the future of TQM: Internal and external driving factors, managing business improvement and quality. Implementing key tools and techniques, Blackwell publishing Ltd, UK.

Mentzer, J. T. (2004). Fundamentals of supply chain management: twelve drivers of competitive advantage. Sage.

Naumann, F., \& Rolker, C. (2000). Assessment Methods for Information Quality Criteria. In Proceedings of the International Conference on Information Quality. In Proceedings of the 5th International Conference on Information Quality. (pp 148-162), Boston, USA.

Ndirangu, N. (2010). Relevance of TQM or business excellence strategy implementation for enterprise resource planning, a conceptual Study

Onwuegbuzie, A. J., \& Collins, K. M. (2007). A typology of mixed methods sampling designs in social science research. The qualitative report, 12(2), 281-316.

Perona, M., \& Miragliotta, G. (2004). Complexity management and supply chain performance assessment. A field study and a conceptual framework. International journal of production economics, 90(1), 103-115.
Porter, M. E. (1985). Competitive advantage: creating and sustaining superior performance. 1985.

Roushdy, M., Mohamed, M., Hesham, S., Elzarka, S., \& Hafez, L. (2015). Investigating the Impact of Suppliers Relationship Management on Firms' Performance: A Multiple Case Study Approach on Manufacturing Companies in Egypt. In Proceedings of the 2015International Conference on Operations Excellence and Service Engineering Orlando, Florida, USA, September (pp. 10-11).

Ryu, S., Park, J. E., \& Min, S. (2007). Factors of determining longterm orientation in inter-firm relationships. Journal of Business Research, Vol.60, No.12, pp.1225-1233.

Sambasivan, M., Siew-Phaik, L., Mohamed, Z.A., \& Leong, Y.C. (2013). Factors influencing strategic alliance outcomes in a manufacturing supply chain: role of alliance motives, interdependence, asset specificity and relational capital. International Journal of Production Economics, Vol.141, pp. 339-351

Saunders, M., Lewis, P., \& Thornhill, A. (2009). Understanding research philosophies and approaches. Research methods for business students, 4, 106-135.

Sekaran, U. (2003). Research methods for business. Hoboken.

Spekman, R.E., Kamauff, Jr. J.W. \& Myhr, N. (1998). An empirical investigation into supply chain management: A perspective on partnerships. Supply Chain Management, 3(2): 53-67

Stevenson, W. J., \& Hojati, M. (2007). Operations management (Vol. 8). Boston: McGraw-Hill/Irwin.

Ul-Hassan, M., Mukhtar, A., Qureshi, S. U., \& Sharif, S. (2012). Impact of TQM practices on firm's performance of Pakistan's manufacturing organizations. International Journal of Academic Research in Business and Social Sciences, 2(10), 232.

Wei, C-C., Liang, G-S. \& Wang, M-J.J. (2007). A comprehensive supply chain management project selection framework under fuzzy environment. International Journal of Project Management, 25(1): 627-636

Yew Wong, C., StentoftArlbjørn, J., \& Johansen, J. (2005). Supply chain management practices in toy supply chains. Supply Chain Management: An International Journal, 10(5), 367-378.

Zailani, S., \& Rajagopal, P. (2006). The effects of Information Quality on Supply Chain Performance: New Evidence from Malaysia. In LatifAlHakim (Ed.), Information Quality Management: Theory and Applications, Chapter XII (pp. 275- 290) IGI Global, ISBN: 1599040247.

Zaman, K. (2011). Review of Pakistan pharmaceutical industry: SWOT analysis. International Journal of Business and Information Technology, 1(2).

Zhenxin, Yu, Hong, H. \& Cheng, T. C. (2001) "Benefits of Information sharing with supply chain partnerships", Industrial Management \& Data Systems, Vol. 101 No. 3, pp. 114-119

$--0--$

Online Archive: https://abc.us.org/ojs/index.php/abr/issue/archive 